\title{
The spider genus Tracbelas L. Koch, 1872 (Aranei: Corinnidae) in Russia
}

\section{Пауки рода Tracbelas L. Koch, 1872 (Aranei: Corinnidae) России}

\author{
Yuri M. Marusik ${ }^{1}$, Mykola M. Kovblyuk ${ }^{2}$ \\ Ю.М. Марусик ${ }^{1}$, Н.М. Ковбцюк ${ }^{2}$
}

${ }^{1}$ Institute for Biological Problems of the North, RAS, Portovaya Str. 18, Magadan 685000 Russia. E-mail: yurmar@mail.ru
Институт Биологических Проблем Севера ДВО РАН, ул. Портовая 18, Магадан 685000 Россия.
${ }^{2}$ Zoology Department, V.I. Vernadsky Taurida National University, Yaltinskaya Str. 4, Simferopol 95007 Ukraine. E-mail: kovblyuk@mail.ru
Кафедра зоологии, Таврический национальный университет им. В.И. Вернадского, ул. Ялтинская 4, Симферополь 95007 Украина.

KEY WORDS: Trachelas, new species, Khabarovsk Province, Russia.

КЛЮЧЕВЫЕ СЛОВА: Trachelas, новый вид, Хабаровский край России.

ABSTRACT. Three species of Trachelas are recorded from Russia: T. minor O. Pickard-Cambridge, 1872, T. japonicus Bösenberg \& Strand, 1906 and T. tanasevitchi sp.n. (Bolshekhekhtsyrski Reserve Khabarovsk Prov., +). All species are described and illustrated.

РЕЗЮМЕ. Три вида рода Trachelas отмечены в России: T. minor O. Pickard-Cambridge, 1872, T. japonicus Bösenberg \& Strand, 1906 и T. tanasevitchi sp.n. (Большехехцирский заповедник, Хабаровский край, +). Приведены описания и иллюстрации этих видов.

\section{Introduction}

Trachelas L. Koch, 1872 is a fairly large genus with 86 species distributed almost worldwide [Platnick, 2010] and is apparently absent only from Australia and New Zealand. Recently, all Palaearctic representatives of this genus were revised in three independent studies [Bosselaers et al., 2009; Feng et al., 2009; Kovblyuk \& Nadolny, 2009]. Bosselaers et al [2009] revised all eight species from the Mediterranean region and described one new species from the Iberian Peninsula. The paper of Feng et al. [2009] revised all Chinese members of the genus (six species altogether) and described two new species. Kovblyuk and Nadolny [2009] surveyed two species occurring in Crimea and Caucasus. The latter paper demonstrated that Trachelas was not a monophyletic genus and described a new genus, Paratrachelas, for two species. Bosselaers et al (2009) also suggested that Trachelas is not a monophyletic genus. Taking into account new discoveries and transfers, the actual diversity of Trachelas is 87 species, 12 of them from the Palaearctic.

Trachelas is one of two corinnid genera that are known from Russia, the other being Phrurolithus C.L.
Koch, 1839. The diversity of Corinnidae in adjoining countries is higher.

Only two species of Trachelas: T. minor O. Pickard-Cambridge, 1872 and T. japonicus Bösenberg et Strand, 1906, were known from Russia. The former was recently reported from Krasnodar Area and Ingushetia [Mikhailov \& Seifulina, 2003; Kovblyuk \& Nadolny, 2009] and the latter was recorded only from Khabarovsk and Maritime Provinces [Marusik et al., 2007; Marusik, 2009].

While surveying spiders from the Bolshekhekhtsyrski Nature Reserve [Marusik et al., 2007], the first author found $T$. japonicus and one unidentified species. When the revision of Chinese Trachelas was published [Zhang et al., 2009], it became clear that specimen from Bolshekhekhtsyrski Reserve belongs to an undescribed species.

The goal of this paper is the description of the new Trachelas species and its comparison with the sympatric $T$. japonicus.

\section{Material and Methods}

Material treated herein will be deposited in the Zoological Museum of Moscow State University (ZMMU). Specimens were photographed using an Olympus Camedia E-520 camera attached to an Olympus SZX16 stereomicroscope. The images were montaged using "CombineZM" image stacking software. Photographs were taken under $75 \%$ ethanol in dishes of different size with paraffin wax in the bottom. Different sized holes were made in the wax to keep the specimens in the correct position.

Coloration was described from specimens preserved in $75 \%$ ethanol with added glycerin ( $9: 1$ by volume). Legs and palpal segments were measured after separation from the cephalothorax. All measurements are in $\mathrm{mm}$. 


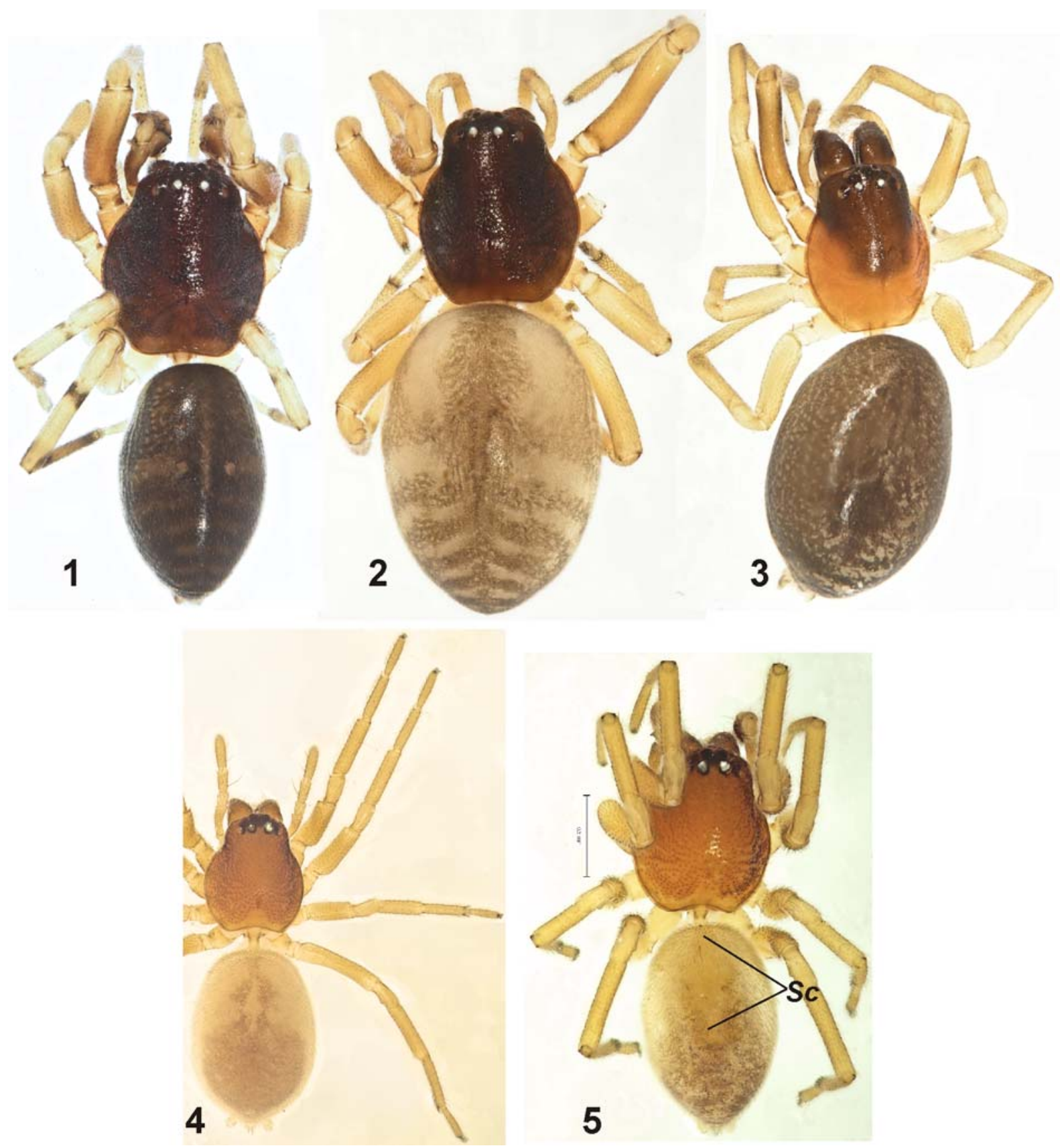

Figs 1-5. Habitus and pattern of Trachelas japonicus (1-2), T. tanasevitchi sp.n. (3) and T. minor (4-5): 1, 5 - male, dorsal; 2-4 female, dorsal. Abbreviations: $S c$ - scutum.

Рис. 1-5. Габитус и рисунок Trachelas japonicus (1-2), T. tanasevitchi sp.n. (3) и T. minor (4-5): 1, 5 - самец, дорсально; 2-4 самка, дорсально.

Museum abbreviations:

$\mathrm{CP}$ - personal collection of A.V. Ponomarev, Rostov-on-Don, Russia;

IBPN - Institute for biological problems of the North, Magadan, Russia

ZMMU - Zoological Museum of Moscow State University.

\section{Species survey}

Trachelas japonicus Bösenberg et Strand, 1906 Figs 1-2, 6-10, 24.

T. j.: Chikuni, 1989: 128, f. 28 (O'P)

T. j.: Paik, 1991: 201, f. 12-23 ( (రా). 

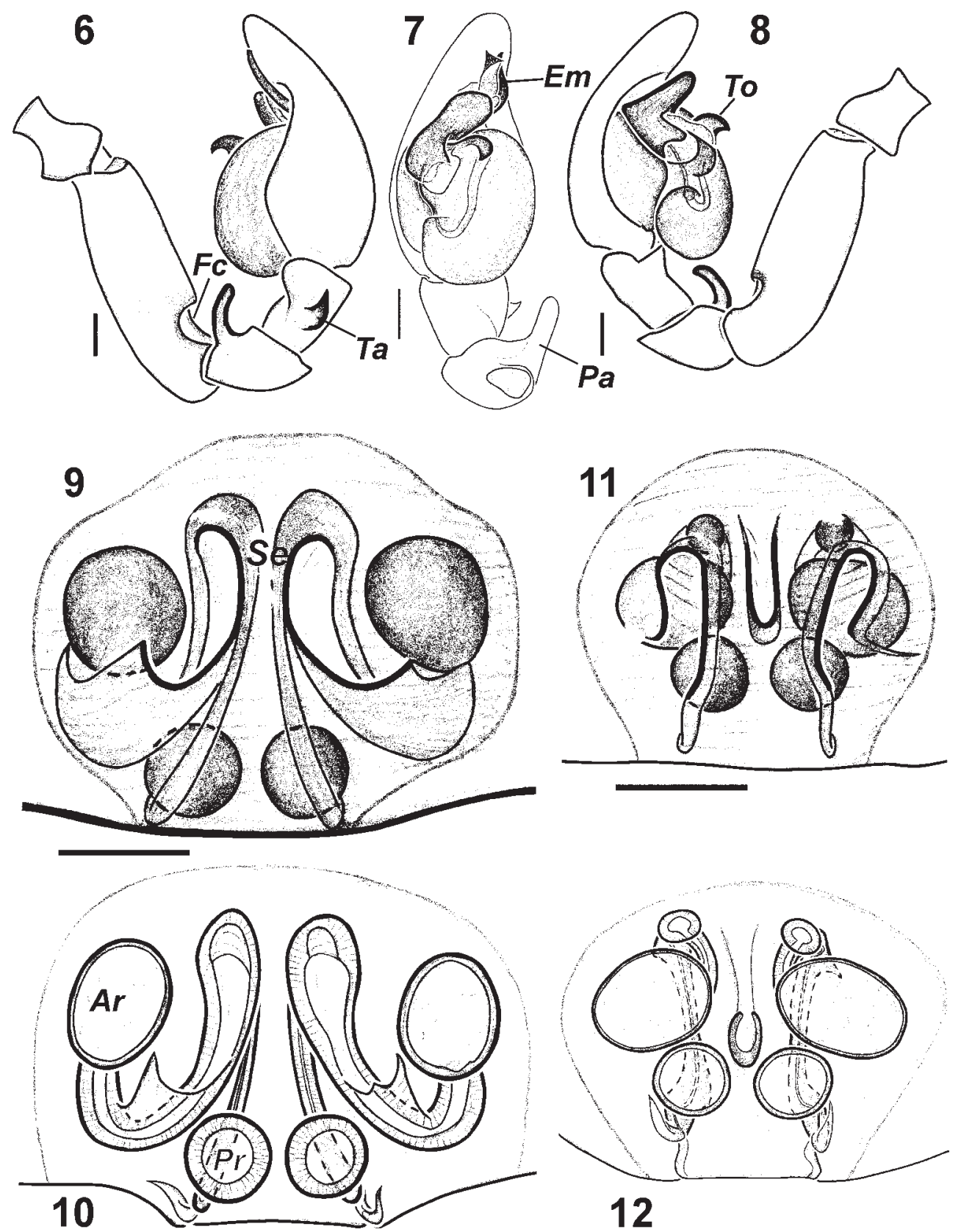

Figs 6-12. Copulatory organs of Trachelas japonicus (6-10) and T. tanasevitchi sp.n. (11-12): 6-8 - male palp, retrolateral, ventral and prolateral, respectively; 9,11 - epigyne, ventral; 10,12 - epigyne after maceration, dorsal. Scale $0.1 \mathrm{~mm}$. Abbreviations: $A r-$ anterior receptaculum; $\mathrm{Em}$ - embolus; $\mathrm{Fc}$ - femoral cavity; $\mathrm{Pa}$ - patellar apophysis; $\mathrm{Pr}$ - posterior receptaculum; $\mathrm{Se}$ - septum; $\mathrm{Ta}-$ tibial apophysis; To - tegular outgrowth.

Рис. 6-12. Копулятивные органы Trachelas japonicus (6-10) и T. tanasevitchi sp.n. (11-12): 6-8 — пальпа самца, ретролатерально, вентрально и пролатерально, соответственно; 9, 11 - эпигина, вентрально; 10, 12 - эпигина после мацерации, дорсально. Масштаб 0,1 мм.

T. j.: Song et al., 2001: 324, f. 209A-H (O'P).

T. j.: Namkung, 2002: 455, f. 35.2a-b (○ొ + ).

T. j.: Zhang et al., 2009: 51, figs. 23-35 (O't).

T. j.: Kamura, 2009: 553, f. 2-2-64-18-21.

For all references see Platnick [2010].

FAUNISTIC RECORDS FROM RUSSIA: Kim \& Kurenshchikov, 1995: 58; Marusik et al., 2007: 42 Khabarovsk Prov.
MATERIAL. RUSSIA. Khabarovsk Province: $10^{7} 1$ 우 (ZMMU), Bolshekhekhtsyrski Reserve, Klyuch Sosnensky Kordon, 05.2004 (A.V. Tanasevitch); $1 \sigma^{7}$ (ZMMU), Bolshekhekhtsyrski Reserve, Chirki Kordon, 05-06.2004 (A.V. Tanasevitch). Maritime Province: $2 O^{7} \sigma^{7} 3$ 우 (IBPN), Chuguyevka Field Station, ca $43^{\circ} 50^{\prime} \mathrm{N} 134^{\circ} 15^{\prime} \mathrm{E}, 31.07-5.08 .1998$ (Yu.M. Marusik).

DIAGNOSIS. T. japonicus can be easily distinguished from other species found in Russia due the 

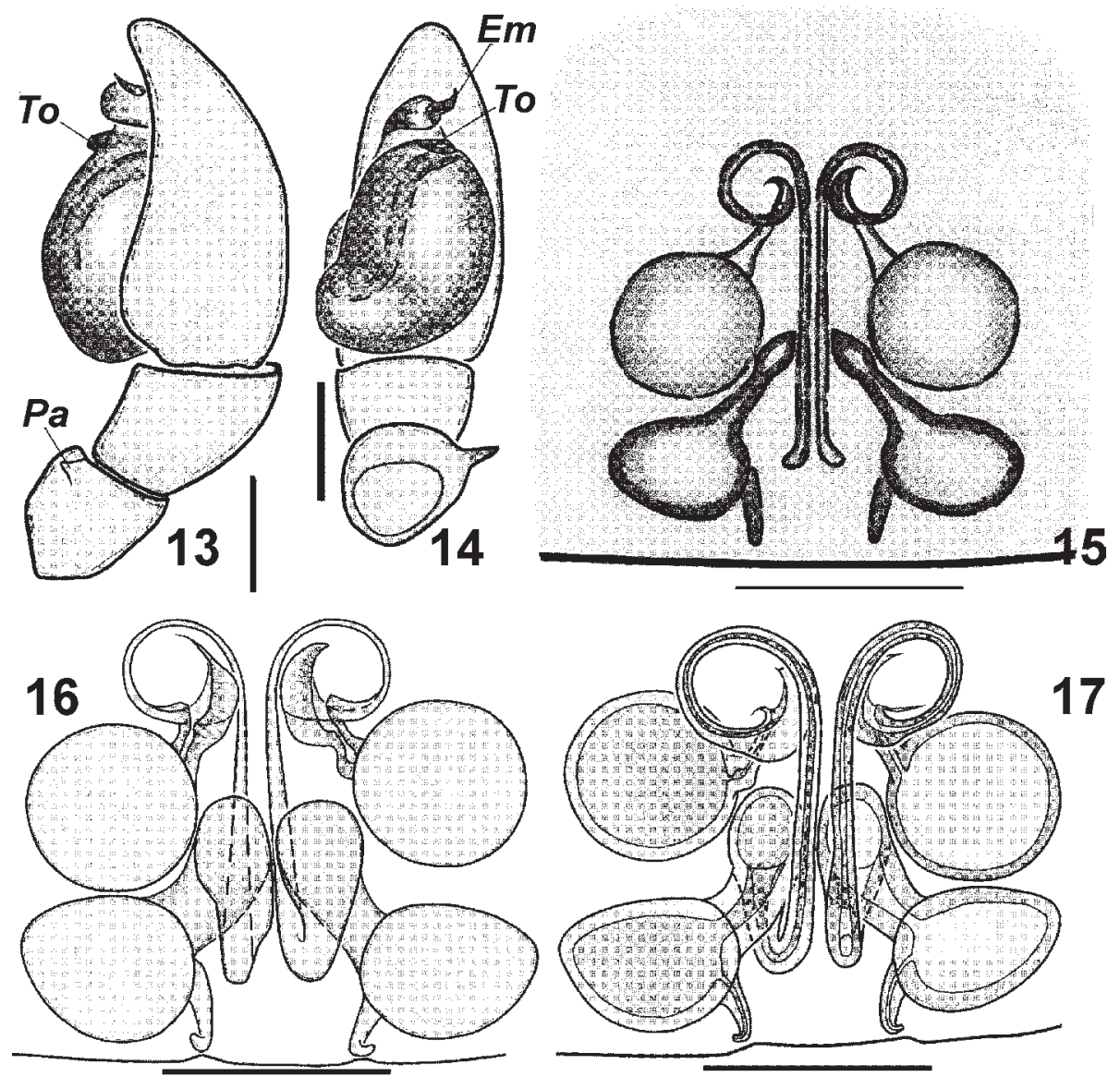

Figs 13-17. Copulatory organs of Trachelas minor from Crimea (after Kovblyuk \& Nadolny, 2009): 13-14 - male palp, retrolateral and ventral, respectively; 15, 17 - epigyne, ventral; 16 - epigyne, dorsal. 16-17 - epigyne after maceration. Scale $0.1 \mathrm{~mm}$. Abbreviations: $E m$ - embolus; $P a$ - patellar apophysis; $T o$ - tegular outgrowth.

Рис. 13-17. Копулятивные органы Trachelas minor из Крыма (по Kovblyuk \& Nadolny, 2009): 13-14 — пальпа самца, ретролатерально и вентрально, соответственно; 15, 17 - эпигина, вентрально; 16 — эпигина, дорсально. 16-17 — эпигина после мацерации. Масштаб 0,1 мм.

dark uniformly coloured carapace and shape of copulatory organs. Males of this species have a long finger like patellar apophysis (short and pointed in T. minor), a tibial apophysis (absent in T. minor) and a massive and long embolus (short in T. minor). Females of this species can easily be recognized by having a thin septum and closely spaced posterior pair of receptacula (wide septum with distinct furrow in $T$. tanasevitchi sp.n.; septum absent and posterior pair of receptaculae spaced by one diameter in T. minor).

DESCRIPTION. Measurements $\left(\sigma^{7} /+\right)$ : total length 2.7 / 3.8; carapace 1.3 / 1.4 length, 1.1 / 1.1 width. Length of leg segments $\left(O^{\top} / q\right)$ :

\begin{tabular}{|l|c|c|c|c|c|}
\hline Legs & femur & patella & tibia & metatarsus & tarsus \\
\hline I & $1.0 / 1.0$ & $0.5 / 0.5$ & $0.8 / 0.8$ & $0.6 / 0.6$ & $0.5 / 0.5$ \\
\hline II & $0.9 / 0.9$ & $0.4 / 0.4$ & $0.7 / 0.7$ & $0.6 / 0.6$ & $0.5 / 0.4$ \\
\hline III & $0.7 / 0.7$ & $0.4 / 0.4$ & $0.5 / 0.5$ & $0.6 / 0.6$ & $0.3 / 0.3$ \\
\hline IV & $0.9 / 1.0$ & $0.4 / 0.4$ & $0.8 / 0.9$ & $0.8 / 0.9$ & $0.4 / 0.4$ \\
\hline
\end{tabular}

Abdomen length $1.5 / 2.4$. Scutum absent in female, but present in male.
Carapace, sternum and chelicerae dark red-brown with vermiculation. Abdomen in female dark-gray with dorsal pattern formed by dark median band and 6 transverse stripes (Fig 2). Abdomen in male darker than in female with indistinct pattern, whole dorsum covered with scutum. Legs and palps yellow-brown in female, male palps dark. Tibia and metatarsus III-IV in male with gray annulations on proximal and distal ends as in Fig 1. Female legs without annulations (Figs 2).

Male palp as in Figs 6-8. Femur with distinct cavity in antero-ventral part, patella with long finger like apophysis (as long as diameter of patella), tibia with claw like retrolateral apophysis located in middle of tibia and directed perpendicularly to axis of the palp; tegulum as high as wide with claw-like outgrowth originating from the base of embolus; embolus complex, thick and long (about of height of tegulum), with bifurcated tip.

Epigyne as in Figs 9-10, 24. Epigynal plate with distinct septum, subequal in width to diameter of posterior pair of receptaculae, margins of septum diverg- 

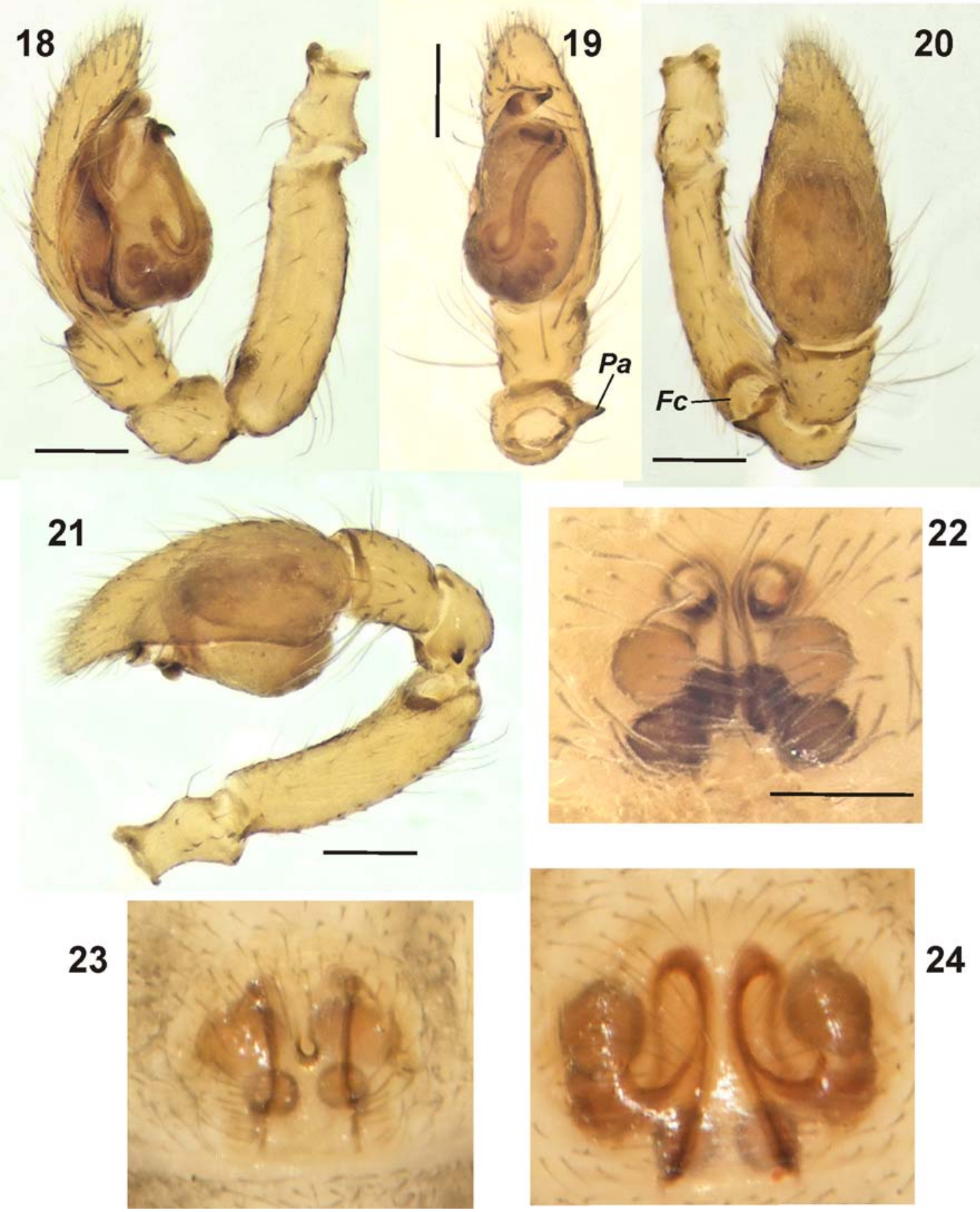

\section{4}

Figs 18-24. Copulatory organs of Trachelas minor (18-22), T. tanasevitchi sp.n. (23) and T. japonicus (24): 18 - male palp, prolateral; 19 - male palp, ventral; 20 - male palp, dorsal; 21 - male palp, retrolateral; $22-24$ - epigyne, ventral. Scale $0.1 \mathrm{~mm}$. Abbreviations: $F c$ - femoral cavity; $P a$ - patellar apophysis.

Рис. 18-24. Копулятивные органы Trachelas minor (18-22), T. tanasevitchi sp.n. (23) и T. japonicus (24): 18 - пальпа самца, пролатерально; 19 - пальпа самца, вентрально; 20 - пальпа самца, дорсально; 21 - пальпа самца, ретролатерально; 22-24 эпигина, вентрально. Масштаб 0,1 мм.

ing posteriorly, copulatory openings located in middle half of epigyne; anterior pair of receptaculae spaced by 2.5 of their diameters; anterior receptaculum more than one diameter from posterior .
DISTRIBUTION. This species is restricted to southeastern Palaearctic and known from Russia (Khabarovsk and Maritime Prov.), northeastern China, Korea and Japan [Marusik et al., 2007; Platnick, 2010]. The record 
from Chuguyevka Field Station is first for the Maritime Province.

\section{Trachelas tanasevitchi sp.n.}

Figs 3, 11-12, 23.

Trachelas sp.: Marusik et al., 2007: 42.

MATERIAL. RUSSIA. Holotype: 1 \& (ZMMU), Khabarovsk Province, Bolshekhekhtsyrski Reserve, Chirki Kordon, 05-06.2004 (A.V. Tanasevitch).

ETYMOLOGY. The species name is a patronym honoring our friend and colleage Andrei V. Tanasevitch (Moscow), who collected the holotype.

DIAGNOSIS. The new species can be recognized due to the pattern of carapace (dark frontal part, and orange posterior part), wide septum with longitudinal furrow (Figs 11-12, 23) lacking all other Trachelas species.

DESCRIPTION. Measurements (+): total length 3.2; carapace 1.2 length, 1.0 width. Length of leg segments $(+)$ :

\begin{tabular}{|l|c|c|c|c|c|}
\hline Legs & femur & patella & tibia & metatarsus & tarsus \\
\hline I & 0.8 & 0.4 & 0.7 & 0.6 & 0.4 \\
\hline II & 0.8 & 0.3 & 0.6 & 0.5 & 0.4 \\
\hline III & 0.6 & 0.3 & 0.4 & 0.5 & 0.3 \\
\hline IV & 0.8 & 0.4 & 0.7 & 0.7 & 0.3 \\
\hline
\end{tabular}

Legs without a spines and cusps. Abdomen length 1.9. Scutum is absent.

Carapace with pattern: frontal part dark red-brown, and posterior part light-brown (Fig. 3). Sternum is lightbrown and smooth. Chelicerae dark red-brown. Carapace and chelicerae with fine vermiculation. Abdomen dark, darker than posterior half of carapace, without dorsal pattern (Fig. 3). Legs and palps are yellowbrown without annulations (Fig. 3).

Epigyne as in Figs 11-12, 23. Epigynal plate with a wide septum (wider than diameter of posterior receptaculum) bearing a longitudinal furrow which terminates in a small pit; margins of septum parallel; anterior pair of receptaculae less than one radius apart; anterior and posterior receptaculae almost touching each other.

DISTRIBUTION. Type locality only.

Trachelas minor O. Pickard-Cambridge, 1872 Figs 4-5, 13-22.

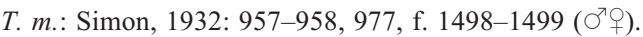

T.m.: Bosselaers et al., 2009: 18, f. 4, 9-15 ( $\sigma^{7}$ ) .

T.m.: Kovblyuk \& Nadolny, 2009: 37, f. 1-36 (O'o)

For all references see Platnick [2010].

FAUNISTIC RECORDS FROM RUSSIA: Mikhailov \& Seifulina, 2003: 96 - Krasnodar Area; Kovblyuk \& Nadolny, 2009: 37 - Ingushetia.

MATERIAL. RUSSIA, Ingushetia: 1 (CP: 46.10.1/1), Megas, sweeping, 26.08.2004 (T.V. Khanov). ABKHAZIA: $160^{7}$ 옹 (IBPN), Sukhum, $42^{\circ} 58.4^{\prime} \mathrm{N} 41^{\circ} 04.04^{\prime} \mathrm{E}$, sandy seashore, cushions of grass, 9-10.10.2004 (Yu.M. Marusik).

DIAGNOSIS. This species can be easily recognized among Trachelas occurring in Russia by its light colouration, absence of a tibial apophysis in male palp and the shape of the receptacula with widely spaced posterior pairs of spermathecae (closely spaced in other species). The distinct copulatory openings are located in the anterior part of the epigynal plate which lacks a distinct septum.

DESCRIPTION. Well described by Kovblyuk \& Nadolny [2009] and Bosselaers et al. [2009]. In addition we can add that males of $T$. minor have a small abdominal scutum, which can be almost invisible in pale specimens. Abdomen lighter than carapace, in some specimens with a distinct pattern of darker median band and several transverse bands in the posterior half (Fig. 4), male with a small scutum, sometimes indistinct.

DISTRIBUTION. This species has a West Palaearctic range and is known from the Iberian Peninsula to Uzbekistan and south to Syria [Kovblyuk \& Nadolny, 2009].

\section{Discussion}

The occurrence of other Trachelas species in Russia is very unlikely. The only species that might be found in Russia along the Black Sea shore is Paratrachelas macultaus (Thorell, 1875). It was recently removed from Trachelas [Kovblyuk \& Nadolny, 2009]. This species ranges from Hungary to Bulgaria and eastward to Crimea [Kovblyuk \& Nadolny, 2009].

ACKNOWLEDGEMENTS. We thank A.V. Tanasevitch (Moscow), who collected the holotype of the new species and A.A. Nadolny (Simferopol), who prepared Figures 1317. This work was supported in part by the RFFI grants \#\# 09-04-01365 and 10-04-01424. The English of the final draft was kindly corrected by A. Russel-Smith.

\section{References}

Bosselaers J., Urones C., Barrientos J.A., Alberdi J.M. 2009. On the Mediterranean species of Trachelinae (Araneae, Corinnidae), with a revision of Trachelas L.Koch, 1872 on the Iberian Peninsula // Journal of Arachnology. Vol.37. No.1. P.15-38.

Chikuni Y. 1989. Pictorial Encyclopedia of Spiders in Japan. Tokyo: Kaisei-sha Publ. Co. 310 pp.

Kamura T. 2009. Trochanteriidae, Gnaphosidae, Prodidomidae, Corinnidae // Ono H. (ed.). The Spiders of Japan with keys to the families and genera and illustrations of the species. Kanagawa: Tokai Univ. Press. P.482-500, 551-557.

Kim J.P., Kurenshchikov D.K. 1995. Preliminary spiders species list of Khabarovsk Territory Southern Part // Korean Arachnology. Vol.11. No.1. P.55-72.

Kovblyuk M.M., Nadolny A.A. 2009. The spider genus Trachelas L.Koch, 1872 in Crimea and Caucasus with the description of Paratrachelas gen.n. (Aranei: Corinnidae) // Arthropoda Selecta. Vol.18. No.1-2. P.35-46.

Marusik Yu.M. 2009. A check-list of spiders (Aranei) from the Lazo Reserve, Maritime Province, Russia // Arthropoda Selecta. Vol.18. No.1-2. P.95-109.

Marusik Yu.M., Tanasevitch A.V., Kurenshchikov D.K., Logunov D.V. 2007. A check-list of the spiders (Araneae) of the Bolshekhekhtsyrski Nature Reserve, Khabarovsk Province, the Russian Far East // Acta Arachnologica Sinica. Vol.16. No.1. P.37-64. 
Mikhailov K.G., Seifulina R.R. 2003. [New records of rare spider Trachelas minor (Aranei, Corinnidae)] // Vestnik zoologii. T.37. No.2. P.96 [in Russian].

Namkung J. 2002. The spiders of Korea. Seoul: Kyo-Hak Publishing Co. 648 pp.

Paik K.Y. 1991. Korean spiders of the genus Trachelas (Araneae: Clubionidae) // Korean Arachnology. Vol.6. No.2. P.197206.

Platnick N.I. 2010. The world spider catalog, version 10.5. American Museum of Natural History, online at http://research.amnh. org/entomology/spiders/catalog/index.html

Simon E. 1932. Les arachnides de France. Tome 6. Synopsis general et le Catalogue des espèces françaises de l'ordre des Araneae: 4e partie. Paris. P.773-978.

Song D.X., Zhu M.S., Chen J. 2001. The Fauna of Hebei, China: Araneae. Hebei: Hebei Science and Technology Publishing House. 510 pp.

Zhang F., Fu J.-Y., Zhu M.-S. 2009. A review of the genus Trachelas (Araneae: Corinnidae) from China // Zootaxa. No. 2235. P.40-58. 